\title{
Kimbundu Language
}

National Cancer Institute

\section{Source}

National Cancer Institute. Kimbundu Language. NCI Thesaurus. Code C153981.

A Niger-Congo Bantu language spoken by the Ambundu people of Angola. 